\title{
The Effects of a Classical Poetry Program on Aesthetic Language Expression and Chinese Character Recognition of Four-year-old Chinese Children
}

\author{
Han Chunhua ${ }^{1}$, Naya Choi $^{2}$, Yi Soon-Hyung ${ }^{2}$ \\ Department of Preschool Education, Lingnan Normal University, Zhanjiang, China ${ }^{1}$ \\ Department of Child Development \& Family Studies, Seoul National University, Seoul, Korea ${ }^{2}$ \\ 고전시가를 활용한 언어교육 프로그램이 중국 4세 유아의 \\ 심미적 언어표현 및 한자인식에 미치는 효과 \\ 한춘화 $^{1}$, 최나야 ${ }^{2}$, 이순형 ${ }^{2}$ \\ 중국 영남(岭南)사범대학교 학전교육학과 ${ }^{1}$, 서울대학교 아동가족학과 ${ }^{2}$
}

Objectives: The purpose of this study was to develop a language education program using classical poetry and to verify its effects on aesthetic language expression and Chinese character recognition in young Chinese children.

Methods: In this study, 98 four-year-olds from two kindergartens in Guangzhou, China, were divided into an experimental group and control group. They participated in a total of 16 language program sessions of 30 minutes. The effectiveness of the language education program, using classic poetry was explored through a mixed study method. Covariance analysis, speech analysis and FGI were performed to examine the effects of this program on the children's aesthetic language expression and Chinese character recognition of children.

Results: First, the language education program using classical poetry, significantly improved participants' aesthetic expression. They attempted to imagine, express themselves using their own experiences, and carefully read the main character's feelings. Second, the program had a significant effect on the children's Chinese character recognition. After the program, they began to exhibit distinct character traits in their name writing.

Conclusion: Children's language ability grows when they engage in natural language activities using classical poetry that reflects culture, rather than pouring over or memorizing it.

Keywords: classical poetry, language education programs, aesthetic language expression, chinese character recognition

\begin{abstract}
서론
형식적 문해 지도를 받기 이전에 유아가 주변의 문해 환경과

Corresponding Author: Naya Choi, Department of Child Development \& Family Studies, Seoul National University, 1, Gwanak-ro, Gwanak-gu, Seoul, Korea

E-mail: choinaya@snu.ac.kr
\end{abstract}

자연스럽게 접하면서 그를 탐색하는 과정에 읽기와 쓰기와 같 은 공식적 문해능력의 토대를 다지는 것은 유아기의 중요한 발달과업이다. 최근 다양한 언어집단에서 유아기 언어발달

(C)The Korean Association of Child Studies

This is an Open Access article distributed under the terms of the Creative Commons Attribution Non-Commercial License (http:// creativecommons.org/licenses/by-nc/4.0) which permits unrestricted noncommercial use, distribution, and reproduction in any medium, provided the original work is properly cited. 
의 특수성에 따른 다양한 연구들이 활발하게 일어나고 있다 (Han, Choi, \& Yi, 2018). 다양한 언어권의 유아교육 현장에서 는 유아들의 문해 발달을 돕기 위해 유아들에게 적절하고 풍 부한 문해 자극을 제공하여 자유롭게 언어를 탐색하도록 격려 함으로써 유아들이 듣기, 말하기, 읽기 및 쓰기에 대한 흥미를 가지게 할 수 있다(Yopp \& Yopp, 2000).

문해에 대한 최근 관점에서는 문해가 단지 읽기와 쓰기만 이 아닌, 듣기와 말하기 등 의사소통의 모든 측면을 포함한다 고 본다. 영유아기 언어표현 능력과 이후 문어 발달 간의 관 계는 폭넓은 연구를 통해 입증된 바 있다(Hay, Elias, FieldingBarnsley, Homel, \& Freiberg, 2007; Ruan, Georgiou, Song, Li, \& Shu, 2018). 모국어의 종류와 상관없이, 유아기의 언어표현은 유아가 다른 사람과 효율적으로 의사소통을 하기 위해 구어 능력뿐만 아니라 자료의 정보와 의미를 파악해 내는 기술을 포함하는 능력으로, 3 세경에 온전한 문장수준으로 나타나고 4 세경에는 자신의 생각 및 감정을 능숙하게 표현하는 수준에 이르게 된다(Erika, 2001). 즉, 언어표현이란 상대방에게 전달 하고자 하는 내용을 자신의 생각이나 느낌과 결합하여 단어와 문장의 재배치를 통해 창의적으로 표현하는 것이다(Jung \& Hwang, 2013).

유아들의 언어표현력은 기존에 습득한 언어 내용과 수준 을 기반으로 부단한 시행착오의 과정을 거쳐 점차 터득해 가 게 되는데 아동문학 작품을 접하는 기회가 많거나 성인들과의 상호작용이 많은 등 언어적 자극이 풍부한 환경에서 생활하 는 유아들은 언어표현 수준이 높다(S. J. Kim, 2012). 유아는 문 학작품을 접할 때 그 내용을 기존 지식, 경험, 생각, 느낌과 결 부하여 이해하고 이야기로 표현한다. 언어표현의 과정에서 정 확한 어휘와 문법, 적절한 문장 구조로 표현하는 것도 중요하 지만 상대방에게 전달하고자 하는 내용을 보다 감정과 느낌이 생생한 아름다운 말로 표현하는 것 또한 중요하다. 즉, 유아들 이 심미적 태도를 갖게 하기 위해 형식에도 주목해야 하지만, 전달하고자 하는 내용에 대한 지각적 파악, 확장된 상상력, 일 상생활과 자연현상의 풍부한 감지, 개인의 자유로운 표현에 대한 의지를 갖게 해야 한다. 유아기에는 직관적인 사유를 하 기 때문에 미적인 면에서 오히려 성인보다 뛰어날 수도 있다 (Schirrmacher, 2005). 때문에 유아에게 풍부한 감성과 심미적 태도 및 창의력을 키울 수 있는 문학 활동과 환경을 시의적절 하게 제공하면 유아의 심미적 능력을 향상시키는 데 효과적이 다. 심미적 언어표현은 유아가 문학작품에 내재된 심미적 가 치를 향유하고 이에 대한 반응을 통해 자신의 심미적 경험을 적절한 단어와 문장으로 표현하는 것이다(J. Kim, 2016). 유아
들의 심미적 언어표현의 향상을 효과적으로 도울 수 있는 문 학으로 시가 활용되어 왔다. J.-S. Kim (2002)은 심미적 언어표 현을 시의 내용이나 시적 요소에 대해 판단하기, 상상하기, 감 정표현하기, 연상하기로 구분하였다. 이 연구에서는 유아들이 중국의 고전시가의 내용과 이미지에 대해 판단하고, 상상하 며, 좋아하는 부분을 언급하고 감정을 표현하며 연상하는 능 력을 심미적 언어표현으로 조작적으로 정의하고, 고전시가 프 로그램이 유아의 심미적 언어표현을 증진시키는지 살펴보고 자 한다.

유아기 문해 발달에서 또 하나의 중요한 영역으로 읽기와 쓰 기의 기초가 되는 문자 인식을 들 수 있다. 유아의 문해능력 중 인쇄물에 대한 인지, 문자의 의미와 형태 및 역할에 대한 인식은 유아의 향후 읽기와 쓰기 발달을 예측한다(Dong, Li, Wu, Rao, $\& \mathrm{Zhu}, 2014)$. 문해 환경과 환경인쇄물은 유아의 문자에 대한 지식과 문어에 대한 민감성을 키워주므로, 유아와 문해 환경과 의 역동적 상호작용을 통해 초기 문해발달이 이루어진다.

그런데 문자 체계의 종류에 따라 유아들의 문자인식도 다 양한 패턴으로 발달한다. 예를 들면, 영어권 유아들은 3세에 10 개 정도의 알파벳 이름을 알기 시작하여 4 세에 더욱 광범위 한 지식을 보유하고, 자소-음소 대응규칙(grapheme-phoneme correspondence rules)에 대한 인식도 서서히 발달하게 되면서 해독이 가능하게 된다(Choi, 2007). 역시 음소문자인 한글을 쓰는 유아들도 4세경에 자소-음소 대응 규칙을 통해 받침 없 는 글자에 대한 해독이 가능해지고 5세에는 받침이 있는 글 자도 해독이 가능하다(Yoon, 2001). 그러나 표의문자(表意文 字)로서, 한 글자가 한 음절을 나타내는 음절문자인 한자를 사 용하는 중국 유아는 음소문자 유아들과 다른 문자인지 기술 을 필요로 한다(Everson, 2011). 한자의 특성을 살펴보면 다음 과 같다. 첫째, 한자는 형(形)으로 의(意)를 표시하는 문자이다 (Lo-Philip, 2014). 둘째, 한자가 기록하는 음운 단위는 음절로, 한자의 모양은 음소와 대응되지 않고 자소-음소 대응 규칙 또 한 약한 반면, 형태와 의미의 관계가 비교적 강하기 때문에 유 아가 한자를 습득할 때 한자를 그림으로 읽고 전체적으로 기 억한다. 마지막으로 한자는 정방형의 평면구조(方块字)로 공 간적 구조를 가지고 있어 유아의 공간 인지 능력을 필요로 한 다(Opitz, Schneiders, Krick, \& Mecklinger, 2014). 즉, 한자는 필 획, 부수, 부건, 편방 등의 복잡한 구조가 있어, 한자 초기 학습 자로서의 유아는 한자를 하나하나의 서로 다른 도형으로 기 억하고 인지하게 된다. 어린 중국 유아들의 한자인식 과정에 대해서 많은 연구자들의 관심이 집중되고 있지만 $(\mathrm{Li} \& \mathrm{Liu}$, 2007; Li, Shu, McBride-Chang, Liu, \& Peng, 2012; Ruan et al., 
2018), 발달적으로 적합한 언어 교육 프로그램의 구성과 시행 을 통해 유아의 한자인식에 대한 효과를 살펴본 경우는 매우 드물다. 따라서 이 연구에서는 고전시가를 활용한 언어 교육 프로그램이 중국 유아의 한자인식을 증진시킬 수 있는지 검증 해보고자 한다.

유아들의 문해 발달을 돕기 위해 발달특성에 적합한 문학 을 매개체로 활용한 언어교육 활동이 적합하다. 특히 고전적, 전통적인 형식과 내용의 시와 노래가 유아교육에 풍부하게 활 용되어 왔다. 영어권 나라들에서는 '마더구스'를 활용한 언어 활동을 통해 유아의 문해 발달에 긍정적 효과를 거둔 사례가 많이 보고되었고(Han et al., 2018; Terrett, White, \& Spreckley, 2013) 한국에서도 유아교육 현장에서 전래동요를 활용한 언 어교육 프로그램들이 활발히 이루어지고 있다. 전래동요 프로 그램의 효과를 살펴본 연구들에서는 전래동요가 유아의 어휘 력, 이야기 구성력 등 언어능력에 긍정적인 효과를 가져 온다 고 보고하였다(Eom, Kang, \& Bark, 2007).

중국에서는 유아의 모국어에 대한 흥미를 일으키고 그들의 언어발달을 자극하는 교수매체로 고전시가를 활용할 데 관한 연구들이 최근 이루어지고 있다(Xu, 2015). 한편, 현재까지 중 국 고전시가를 유아교육에 적용한 논문을 살펴보면, 중국 아 동문학의 한 장르로서의 고전시가는 중국 문화의 훌륭한 문 화유산으로서 묘사, 상상의 수법, 비유적 수법이 다양하게 어 우러져 표현이 생동하고 윤곽이 선명하며 생생한 느낌을 주 는 특성이 있다 $(\mathrm{Lu}, 2015)$. 이러한 시각적 이미지가 강한 고전 시가를 통해 유아들은 시를 읋으면서 소리의 리듬과 이미지 를 결합하여 그 아름다움을 머릿속에 그려낼 수 있다. 유아들 은 감수성을 지니고 있어 자신의 내면화된 느낌이나 생각을 살아 숨 쉬는 언어, 메타포를 만들어내는 독특한 능력을 가지 고 있는 것으로 알려져 있다(J. Kim, 2016). 그들은 자신의 경 험을 바탕으로 내면의 생각을 시적이고 창의적인 언어로 표현 할 수 있다는 것이다. 또한 중국 고전시가는 음절이 고르며 압 운을 하는 특성을 가지고 있어 유아의 청각적 심미능력 발달 을 도모할 수 있을 뿐 만 아니라 유아들에게 모국어의 아름다 움을 느끼게 할 수 있다(Liu, \& Teng, 2013). 특히, 유아의 언어 발달에 맞게 구성된 고전시가들은 형식상 간결하지만 감각적 심상과 상징적 심상이 두드러지고 이미지가 강한 특성을 가지 고 있어, 유아의 심미적 언어표현력을 향상시키는 데 도움을 줄 수 있다(Zhang \& Yang, 2013). 또한, 고전시가 활용한 유아 언어교육 활동 중 시의 내용을 우아한 서체로 적절히 활용하 면 유아의 문자에 대한 흥미를 일으킬 수 있다. 그 중 시의 중 심 내용을 나타내는 상형자는 글자 모양이 그 의미와 비슷한
특성을 가지고 있어 유아에게 쉽게 인지될 수 있다. 예를 들어 '人(사람)', ‘口(입)', '火(불)', ‘象(코끼리)' 등 상형자는 글자를 통해 실물을 직접 떠올릴 수 있는 한자들로 시가의 의미지, 심 상과 일맥상통한다.

하지만 중국 고전시가를 활용한 유아 언어교육 활동에 대 한 선행연구들은 문헌고찰과 질적인 연구방법이 주를 이루었 고(Xu, 2015; Yang \& Liu, 2003), 직접 유아들을 대상으로 고전 시가를 활용하여 언어교육 프로그램을 구성하여 그 효과를 다 방면에서 살펴본 연구는 매우 드물다. 이상의 연구 필요성에 따 라, 이 연구에서는 Grafinger (1988)이 제기한 교수학습설계모 형(Instructional Systems Development [ISD]) 중 (Analysis, Design, Devlopment, Implementation, Evaluation [ADDIE]) 모형에 근거 하여 고전시가를 활용한 언어교육 프로그램을 구성하고 중국 유아들을 대상으로 적용하여 그 효과를 살펴보고자 한다. 구체 적으로, 유아의 심미적 언어표현을 작품에 대한 판단하기, 상상 하기, 좋아하는 부분 언급하기, 감정 표현하기 및 연상하기 등 으로 구분하고, 한자인식을 한자 고르기, 그림이 나타내는 한자 고르기 및 한자가 나타내는 그림 고르기 등으로 나누어 이들 하 위 영역에 미치는 효과를 양적인 방법으로 검증할 것이다. 또한 유아의 심미적 언어표현과 한자인식의 변화과정을 질적 분석 을 통해 심도 깊게 살펴볼 것이다. 다음, 실험집단 유아와 교사 와의 포커스 그룹 면담을 통해 프로그램을 전반적으로 평가하 는 것을 목적으로 한다. 이를 통해 유아기의 심미적 언어표현과 한자인식의 향상을 위한 보다 효율적인 프로그램의 내용과 방 향에 대해 시사점도 얻을 수 있을 것으로 본다.

이상의 목적을 위해 다음과 같은 구체적인 연구문제를 설 정하였다.

\section{연구문제 1}

고전시가를 활용한 언어교육 프로그램이 유아의 심미적 언어 표현에 미치는 효과는 어떠한가?

1-1. 고전시가를 활용한 언어교육 프로그램은 유아의 심미적 언어표현에 유의한 영향을 미치는가?

1-2. 고전시가를 활용한 언어교육 프로그램에 참여한 유아들 의 심미적 언어표현은어떤 변화를 보이는가?

\section{연구문제 2}

고전시가를 활용한 언어교육 프로그램이 유아의 한자인식에 미치는 효과는 어떠한가? 
2-1. 고전시가를 활용한 언어교육 프로그램은 유아의 한자인 식에 유의한 영향을 미치는가?

\section{2-2. 고전시가를 활용한 언어교육 프로그램에 참여한 유아들 의 한자인식은 어떤 변화를 보이는가?}

\section{연구방법}

\section{연구대상}

이 연구는 중국 광동성(广东省) 광저우시(广州市)에 위치한 $\mathrm{H}$ 유치원과 $\mathrm{Y}$ 유치원의 4 개 학급의 만 4 세 유아 98 명을 연구 대상으로 하였다. 그 중 실험집단은 49 명 (남아 25 명, 여아 24 명)이고, 통제집단은 49명(남아 27명, 여아 22명)으로 분류하 였다. 이 연구에서 4 세 유아를 연구 대상으로 선정한 이유는 다음과 같다. 선행연구 고찰을 통해, 4 세는 3 세와 달리 유아 의 언어 상징 기능이 급격히 발달하는 시기(Brooks \& Kempe, 2012)이므로 고전시가를 활용한 프로그램은 유아들의 심미적 언어표현과 한자인식 발달에 긍정적 효과를 미칠 수 있다고 가정해 볼 수 있다. 또한 5세 유아는 유치원에서 초등학교 진 학을 위한 한자에 관한 교육을 다소 받는 경향이 있는 반면, 4 세 유아는 기본적으로 한자에 대한 학습이 이루어지지 않았기 때문에 프로그램의 효과를 검증하는 데 더 효과적이라고 할 수 있다. 마지막으로, 4 세와 5세 유아 각각 5 명을 대상으로 예 비조사를 해본 결과, 5 세 유아는 심미적 언어표현 및 한자인식 검사에서 정확하게 대답하는 확률이 $89.4 \%$ 에 달하는 반면, 4 세는 심미적 언어표현과 한자인식 검사에서 정확하게 대답하 는 확률이 $52.4 \%$ 로 프로그램의 효과를 확연히 검증할 수 있다 고 가정하였다.

연구대상을 선정함에 있어서 가정의 소득 수준과 언어 환경 요인을 고려하였다. 프로그램 시행 전 부모용 질문지 를 통한 자료에 의하면, 연구대상 가정의 월 평균 소득은 $10,000-15,000$ 위안이 가장 많았고(45.8\%), 5,000 10,000위 안(23.4\%)과 15,000 20,000위안(19.6\%)이 그 뒤를 이었다. 또 한, 65 명의 유아가 가정에서 주로 보통말(普通话)을 사용였고, 22 명의 유아가 보통말과 광동어(广东语)를 섞어서 사용하였 으며, 11 명의 유아는 보통말, 광동어 외 기타 방언(方言)을 함 께 사용하는 것으로 나타났다.

실험집단 유아 중 고전시가를 활용한 언어교육 프로그램의 16 차시에 모두 참여한 유아 중 교사와의 면담을 통해 유아의
언어발달 특성과 프로그램 참여도 및 표현도에 따라 상, 중, 하 로 분류한 후, 각 수준 별로 무작위로 남아 1 명씩과 여아 1명 씩 총 6명의 유아를 사례분석의 대상으로 선정하였다.

\section{연구도구}

\section{심미적 언어표현 측정 도구}

심미적 언어표현 측정 도구는 Many \& Wiseman (1992)의 동시 감상 반응 분석 도구를 J.-S. Kim (2002)이 수정 - 보완한 감상 반응 분석도구 중 심미적 언어표현 부분을 기초로 중국 유아 의 언어발달 특성에 접합하도록 문항을 수정하여 개발하였다. 이 척도는 판단하기, 상상하기, 좋아하는 부분 언급하기, 감정 표현하기 및 연상하기의 5 개 하위항목으로 구성되었다. 하위 범주의 문항 수는 '판단하기'의 4문항, '상상하기'의 3 문항, '좋 아하는 부분 언급하기'의 3 문항, '감정표현하기'의 2 문항, '연 상하기' 2 문항으로 총 14 문항으로 구성되었다. 또한 이 검사에 서는 아동학과 유아교육과 교수 4 인, 중국문학 전공 전문가 1 명, 경력 3년 이상의 유아교사와 4인과의 협의를 통해 4세 중 국 유아의 발달 특성에 적합하고 그들의 심미적 언어표현을 자극할 수 있다고 판단되는 2 편의 고전시가와 해당 칼라 그 림 자료를 사용하였다. 사전 - 사후 검사에 사용된 고전시가는 Table 1 과 같다. 검사방법은 고전시가가 쓰여 있는 해당 그림 을 유아들에게 보여줌과 동시에 중국 보통말을 모국어로 사용 하는 보통말 1 급 하 이상 자격을 소지한 30 대 한족 여성이 녹 음한 해당 고전시가를 유아들에게 들려주고 유아에게 그림을 관찰하도록 충분한 시간을 준 다음 유아들에게 질문에 각 문 항의 질문에 응답하게 하였다. 채점방식은 낮은 수준[1점], 평 균[2점], 높은 수준[3점]으로 구분하여 점수하였고 “잘 모르겠 어요.”라고 대답하는 경우 0점으로 처리하여 각 요소별로 유 아가 받을 수 있는 점수는 0점에서 3점이며, 얻을 수 있는 총 점의 범위는 시가 1 편당 0 점에서 42 점이다. 점수가 높을수록 하위범주별 심미적 언어표현 능력이 잘 이루어졌다고 해석할 수 있다. 심미적 언어표현의 전체 내적 합치도(Cronbach's $\alpha$ ) 는 .86으로 나타났으며 각 항목별로는 판단하기 .79, 상상하기 .70 , 좋아하는 부분 언급하기 .65, 감정표현하기 . 76 , 연상하기 .76으로 높은 신뢰도를 보였다. 인터뷰 자료의 분석은 중국 $\mathrm{H}$ 사범대학교 유아교육학과 조교수와 연구자가 집중적 코딩 훈 련과정을 거쳐 채점한 후 일치도를 산출한 결과는 .92었다. 불 일치한 판단의 경우 채점자 간 협의를 거쳐 최종적으로 점수 를 산출하였다. 
Table 1

The Classical Poetry Used for the Test

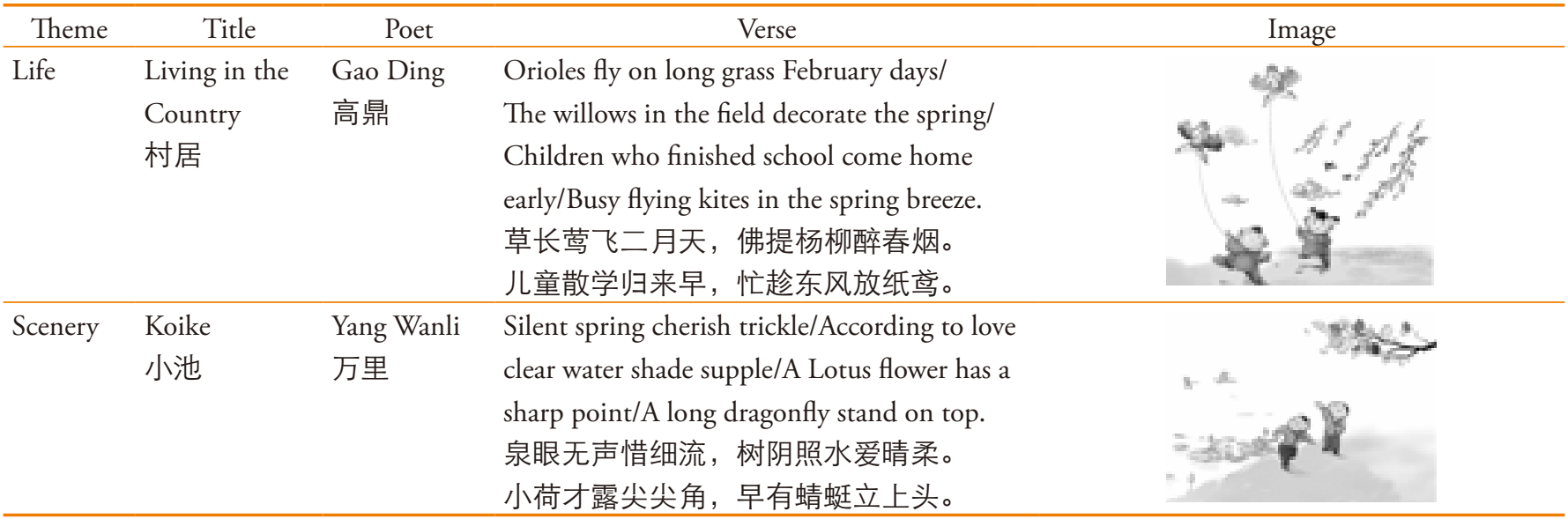

Table 2

Subcategory, Number of Questions, Range of Scores, Examples, and Cronbach's a of Aesthetic Language Expression Tests

\begin{tabular}{lccll}
\hline \multicolumn{1}{c}{ Subcategory } & $\begin{array}{c}\text { Number of } \\
\text { Questions }\end{array}$ & $\begin{array}{c}\text { Range of } \\
\text { Scores }\end{array}$ & \multicolumn{1}{c}{ Examples } & Cronbach's $\alpha$ \\
\hline $\begin{array}{l}\text { Judging } \\
\text { Imagining }\end{array}$ & 4 & $0-12$ & Why does he/it look this way? \\
$\begin{array}{l}\text { Recalling } \\
\text { favorite parts }\end{array}$ & 3 & $0-9$ & Can you imagine what he's thinking? & .79 \\
$\begin{array}{l}\text { Expressing } \\
\text { emotions }\end{array}$ & 2 & $0-9$ & Which part of the poem or picture do you like best? \\
$\begin{array}{l}\text { Associating } \\
\text { Total }\end{array}$ & 2 & $0-6$ & How did this make you feel (the poem and the picture)? & .70 \\
\hline
\end{tabular}

\section{한자인식 측정 도구}

Loh, Tse, \& Tsui (2013)의 한자의 형 · 의(形.意)검사 도구를 이 연구의 연구목적에 맞게 수정·보완하여 사용하였다. 구체적 으로 한자인식 척도는 한자 찾기 10 문항, 그림이 나타내는 한 자 고르기와 한자가 나타내는 그림 고르기가 각각 5 문항씩 총 20문항으로 구성되었다. 본 연구에서 산출된 한자인식 척도 의 내적 합치도(Cronbach's $\alpha$ )는 .88로 각 하위요인별 신뢰도 는 한자 고르기 .87 , 그림이 나타내는 한자 고르기 .74, 한자가 나타내는 그림 고르기 .83 이었다. 또한, 이 척도는 각 하위요인 별로 그 중 ‘그림이 나타내는 한자 고르기’와 ‘한자가 나타내는 그림 고르기' 검사에서 모두 명사이고 프로그램에서 다루지 않은 상형문자를 사용하였다. 유아들에게 있어서 명사는 제일 쉬운 품사로, 단어를 습득할 때 제일 먼저 배우게 된다. 명사가 다른 품사에 비해 가장 구체적이어서 습득에 용이하기 때문이 다(Ellis \& Beaton, 1993).

\section{연구절차}

\section{프로그램의 개발}

이 연구는 교육 프로그램 개발을 위한 교수학습설계모형 (instructional systems development)중에 Grafinger (1988)이 제기 한 $\mathrm{ADDIE}$ 모형에 근거하여 고전시가를 활용한 언어교육 프 로그램을 개발하였다. $\mathrm{ADDIE}$ 모형은 분석, 설계, 개발, 실행 및 평가 다섯 개 단계로 나뉜다(Han et al., 2018). 첫째, 분석 단계에서는 프로그램 내용을 구성하기 위한 교육현장 분석과 교육 대상자 발달 특성 분석 및 기존 연구에 대한 분석이 이루 어졌다. 둘째, 설계 단계에서는 세부 목표 설정, 고전시가 주제 의 선정, 교수방법 설정, 교수내용 위계적 구성 등이 이루어졌 다. 셋째, 개발 단계에서는 실제 프로그램을 개발하고 예비시 행을 통해 내용을 수정 - 보완하였다. 또한 내용의 위계적 구성 과 난이도 등에 대해 전문가 5인의 타당도 검증을 세 차례 받 


\begin{tabular}{|l|}
\hline Phase 1: Analysis \\
\hline - Analysis of the training site \\
- Analysis of the developmental \\
characteristics of educational targets \\
- Analysis of existing studies
\end{tabular}

Phase 2: Design

- Establishment of detailed goals,

- Selection of classical poetry

- Establishment of teaching methods

- Hierarchical structuring of teaching contents

\begin{tabular}{|c|c|c|c|c|}
\hline Phase 3: Development & & Phase 4: Implementation & & Phase 5: Evaluation \\
\hline $\begin{array}{l}\text { - Verification by } \\
\text { preliminary inspection } \\
\text { - Verification by four } \\
\text { experts in early childhood } \\
\text { education and one expert } \\
\text { in Chinese classical poetry }\end{array}$ & $\longrightarrow$ & $\begin{array}{l}\text { - Implementation of programs at } \\
\text { the training site } \\
\text { - } 16 \text { sessions over four weeks. } \\
\text { - } 30 \text { minutes per session }\end{array}$ & $\rightarrow$ & $\begin{array}{l}\text { - Pre-post examination } \\
\text { of aesthetic language } \\
\text { expression and Chinese } \\
\text { character recognition } \\
\text { - Overall assessment of the } \\
\text { program's level of interest } \\
\text { and relevance of content }\end{array}$ \\
\hline
\end{tabular}

Figure 1. Development process and components of the classical poetry program.

았다. 넷째, 실행 단계는 현장에서 프로그램을 적용하는 것을 말한다. 이 프로그램은총 16회기에 걸쳐 시행되었다. 마지막 으로, 평가 단계에서는 프로그램의 효과를 검증하기 위한 사 전 사후 검사와 $\mathrm{FGI}$ 를 통한 프로그램의 효과에 대한 전체적 평가의 과정을 거쳤다.

이 연구는 유아를 대상으로 고전시가를 활용한 선행연구들 (Liu \& Teng, 2013; Lu, 2015)에서 활용 빈도가 가장 높은 고전 시가 8편을 최종 선정하여 고전시가 언어교육 프로그램을 구 성하였다. 또한 유아교육과 아동학 전문가 2 명에게 안면 타당 도 검증을 받아, 선정된 고전시들이 정치 등 성인 중심의 내용 이 아닌, 자연과 일상생활에 관한 시임을 확인하였다. 주제는 동물(1), 계절(2), 풍경(2), 식물(1), 인물(1), 생활(1)로 다양하 게 구성되었다. 이 프로그램은 한 달 동안 주 4회 실시하여 총 16 회 분량으로 구성되었으며, 도입, 전개, 마무리 3 세 단계로 나누어 매 회 30 분씩 실시되었다. 이 프로그램의 고안과정은 Table 3, Table 4와 같으며, 4 명의 아동학, 유아교육 전공 교수 와 1 명의 중국 고전시가 전공 교수, 또한 연구 대상 유치원 원 장, 주임 및 담임교사와의 논의를 거쳐 내용의 적절성에 대한 검증을 받았다.

교수법은 Han et al. (2018)이 사용한 문학작품에 대한 정 보도출식 지도법(efferent reading)과 심미적 지도법(aesthetic reading) 중 주로 심미적 지도법을 활용하여 시가에 대한 감각 적 이미지 표현하기, 듣고 느낀 점 표현하기, 글자의 모양에 따 라 한자의 유래를 탐색하기 등 활동으로 구성하였다.

\section{예비검사}

예비 조사에 앞서, 이 연구는 우선 $\mathrm{E}$ 대학교 연구윤리위원회 의 승인(IRB No. 1704/002-010)을 받았다. 2016년 12월 12일 부터 12 월 16 일까지 중국 광둥성 광저우시에 위치한 $\mathrm{H}$ 유치원 과 $\mathrm{Y}$ 유치원의 4세 유아 6명(그 중 남아 3명, 여아 3명)을 대상 으로 유아의 심미적 언어표현과 한자인식에 대한 예비검사를 실시하였다. 예비검사를 통해, 유아들이 질문을 이해하는 데 어려움이 없는지, 문제의 난이도가 적절한지를 확인하였다. 또한, 고전시가를 활용한 언어교육 프로그램에서 시행하는 주 요 활동을 10 명(남아 6 명, 여아 4 명)에게 시행하여 활동 수준 의 적절성, 내용의 흥미성, 현장 적용성 등을 확인하였다. 또 한, 유치원 주임교사와 담임교사의 참여 관찰을 통해 이 프로 그램에 대한 수정·보완이 이루어졌다.

\section{사전검사}

실험집단 유아에게 고전시가를 활용한 언어교육 프로그램을 시행하기 전, 실험집단과 통제집단 전반 유아를 대상으로 그 들의 심미적 언어표현과 한자인식에 대한 사전검사를 2017년 3 월 13 일부터 28 일까지 실시하였다. 사전검사의 모든 과제는 유치원의 미술실, 도서실 등 독립된 조용한 공간에서 1:1 면접 으로 진행되었고, 유아의 과제 수행 시간은 개인차가 있었으 나, 약 10-15분 정도 소요되었다. 
Table 3

Composition of Classical Poetry Program

\begin{tabular}{|c|c|c|c|c|c|c|}
\hline No. & Theme & Title & Poet & Verse & Image & $\begin{array}{l}\text { Chinese } \\
\text { character }\end{array}$ \\
\hline 1 & Animals & $\begin{array}{l}\text { Goose } \\
\text { 我鸟 }\end{array}$ & $\begin{array}{c}\text { Luo } \\
\text { Binwang } \\
\text { 骆宾王 }\end{array}$ & $\begin{array}{l}\text { Goose, goose, goose, hi! } \\
\text { You with a long-crooked neck sing to the sky. Floating on } \\
\text { green water with feathers in white. With red-webbed feet } \\
\text { stirring in blue dye. } \\
\text { 我鸟、我鸟、鹅, 曲项向天歌。 } \\
\text { 白毛浮绿水, 红掌拨清波。 }\end{array}$ & & 天 \\
\hline 2 & Season & $\begin{array}{l}\text { A Spring } \\
\text { Morning } \\
\text { 春晓 }\end{array}$ & $\begin{array}{l}\text { Meng } \\
\text { Haoran } \\
\text { 孟浩然 }\end{array}$ & $\begin{array}{l}\text { This spring morning in bed I'm lying. } \\
\text { Not to awake till birds are crying. } \\
\text { After one night of wind and showers. } \\
\text { How many are the fallen flowers! } \\
\text { 春眠不觉晓, 处处闻啼鸟。 } \\
\text { 夜来风雨声，花落知多少。 }\end{array}$ & & 花 \\
\hline
\end{tabular}

层楼。

Lush, lush grass on the plain.

Once every year it sears and grows.

4 Plants Grass Bai Juyi Wildfire can not burn it out.

草白居易 The spring breeze blows it back to life.

离离塬上草, 一岁一枯荣。

野火烧不尽, 春风吹又生。

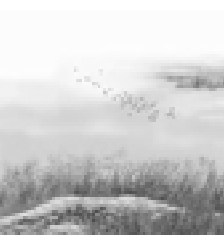

风

Sitting there casually on a waterside lea. A child with disheveled

A Fishing $\quad \mathrm{Hu}$ hair is learning to fish. Answering a stranger's inquiry.

Child Lingneng It just waves,

5 People Child $\begin{gathered}\text { Lingneng } \\ \text { 小儿垂钓 } \\ \text { 胡令能 }\end{gathered}$

For fear that its voice will scare fish away.

蓬头稚子学垂纶, 侧坐莓苔草映身。路人借问遥招手, 怕得鱼惊不应人。

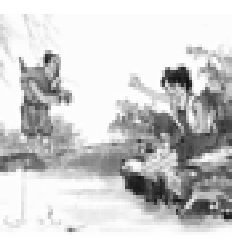

Hoeing millet in mid-day heat.

Sympathy

6 Life

for the

Li Shen

Sweat dripping to the earth beneath.

Peasants

李绅

悯农

Do you know the food on your plate?

Each grain was hard-earned.

锄禾日当午, 汗滴禾下土。谁知盘中餐, 粒粒皆辛苦。

Delighting

in Rain on

7 Season a Spring

Night

春夜喜雨

$\mathrm{Du} F u$

杜甫

A good rain knows its proper time.

It waits until the spring to fall.

It drifts in on the wind, steals in by night. Its fine drops drench,

yet make no sound at all.

好雨知时节, 当春乃发生。随风潜入夜, 润物细无声。

The slender tree is dressed all in emerald all about. A thousand

$\mathrm{He} \quad$ branches droop like fringes made of jade. Do you know by

8 Scenery $\begin{gathered}\text { The Willow } \\ \text { Zhizhang }\end{gathered}$ 柳 $\begin{gathered}\text { Zhom these slim leaves are cut? The wind of early spring is } \\ \text { 贺知章 sharp as scissors. }\end{gathered}$

二月春风似剪刀。 
Table 4

An Example of Classical Poetry Program

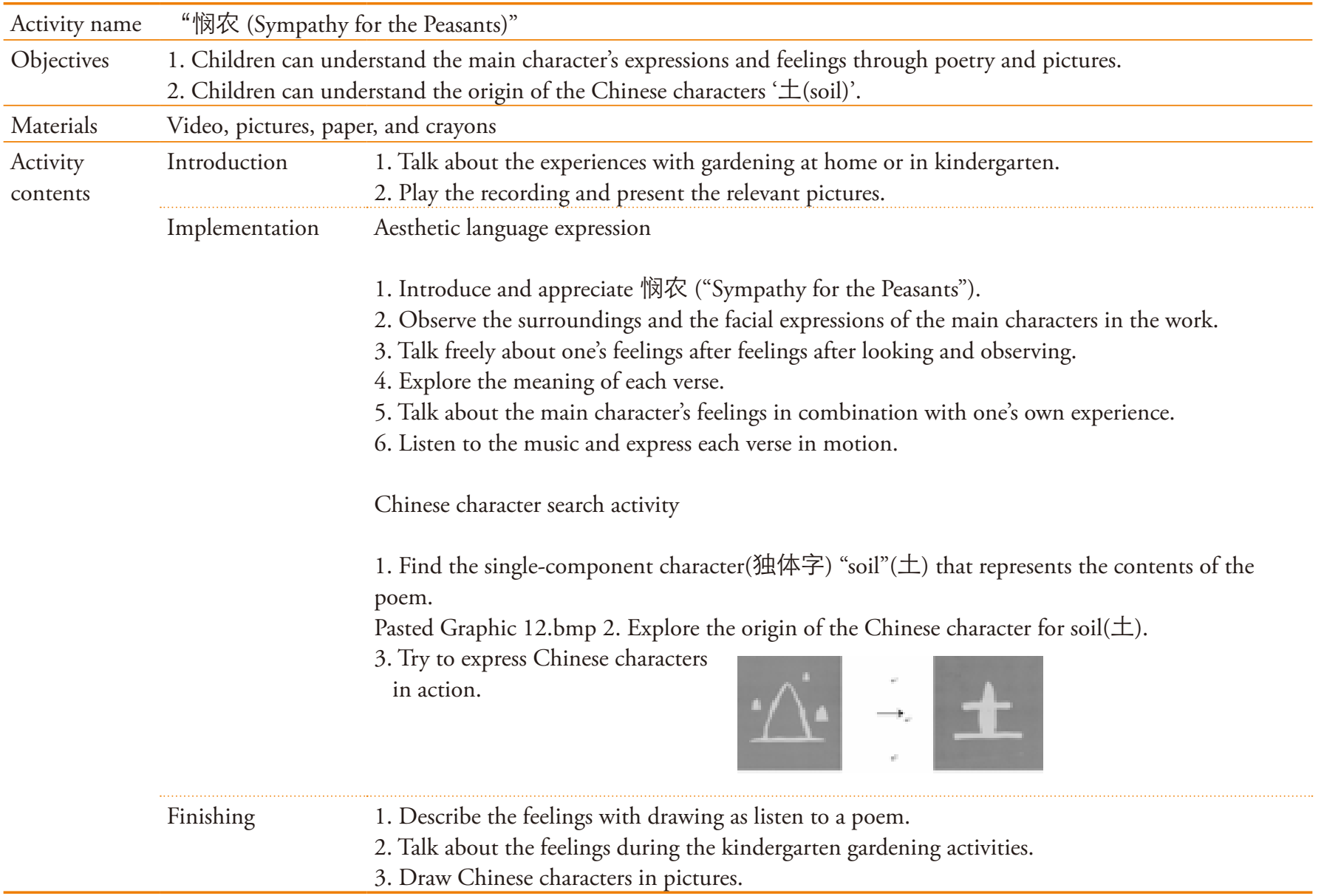

\section{프로그램 시행}

2017년 4월 10일부터 5월 6일까지 평균 일주일에 4회씩 오후 의 자유 놀이 시간을 활용하여 총 16 회의 고전시가를 활용한 언어교육 프로그램을 시행하였다. 시행 시간은 1 차시에 도입 5 분, 전개 20 분, 마무리 5 분으로 총 30 분 소요되었다. 시행 장 소는 유치원 4세반 교실을 활용하였고, 시행 시간은 유치원의 일과 시간 중 자유놀이 시간인 오후에 시행하였다.

\section{사후검사}

고전시가를 활용한 언어교육 프로그램 실시 후 유아의 심미적 언어표현 및 한자인식의 변화량과 그 과정에 어떤 변화를 가 져왔는지 알아보기 위해 사전검사와 동일한 검사 도구를 통한 사후검사를 진행하였다. 조사대상은 사전검사와 동일한 실험 집단과 통제집단의 모든 유아로, 2017년 5월 8일부터 24일까
지 진행하였다.

\section{포커스 그룹 면담}

고전시가를 활용한 언어교육 프로그램의 내용 및 실시 효과에 대해 전반적으로 평가하기 위해 실험집단 유아와 그들의 교 사를 두 그룹으로 나누어 포커스 그룹 면담(FGI)을 실시하였 다. 교사 포커스 그룹은 실험집단 2 개 학급 4 명의 교사와 이루 어졌고, 유아 포커스 면담은 실험집단의 두 개 학급에서 학급 당 6명 유아씩 두 집단을 구성하여 포커스 그룹 면담을 각각 한 번씩 시행하였다. 이 세 그룹의 포커스 그룹 면담은 연구자 가 직접 사회를 맡아 도입, 전개, 마무리의 순으로 진행하였다. 연구자는 전반 프로그램의 집행자였기에 포커스 그룹 면담 과 정에서 두 실험집단 교사와 유아들과 아주 친숙하였고, 질문 을 하고 대답을 유도하는 가운데 보다 자유롭게 교사와 유아 의 행동, 표정, 제스처 등을 포착하여 해석을 할 수 있었다. 또 
Table 5

Difference Between Groups in Aesthetic Linguistic Expressions Before Intervention

\begin{tabular}{|c|c|c|c|c|c|}
\hline Division & Group & $N$ & $M$ & $S D$ & $t$ \\
\hline \multirow[t]{2}{*}{ Judging } & Experimental group & 49 & 1.65 & .69 & \multirow{2}{*}{1.20} \\
\hline & Control group & 49 & 1.49 & .65 & \\
\hline \multirow[t]{2}{*}{ Imagining } & Experimental group & 49 & 1.61 & .70 & \multirow{2}{*}{-1.74} \\
\hline & Control group & 49 & 1.88 & .81 & \\
\hline \multirow[t]{2}{*}{ Recalling favorite parts } & Experimental group & 49 & .73 & .67 & \multirow{2}{*}{.48} \\
\hline & Control group & 49 & .67 & .59 & \\
\hline \multirow[t]{2}{*}{ Expressing emotions } & Experimental group & 49 & 1.49 & .68 & \multirow{2}{*}{.14} \\
\hline & Control group & 49 & 1.47 & .74 & \\
\hline \multirow[t]{2}{*}{ Associating } & Experimental group & 49 & 1.02 & .72 & \multirow{2}{*}{-.87} \\
\hline & Control group & 49 & 1.14 & .68 & \\
\hline \multirow[t]{2}{*}{ Total } & Experimental group & 49 & 6.51 & 2.21 & \multirow{2}{*}{-.50} \\
\hline & Control group & 49 & 6.73 & 2.20 & \\
\hline
\end{tabular}

한 연구자는 포커스 그룹 면담의 전반 내용을 녹음한 후 전사 하여 자료를 구성하였고, 이 결과를 바탕으로 전반 프로그램 에 대해 평가하였다.

\section{자료분석}

수집된 자료는 SPSS 22.0 프로그램(IBM Co., Armonk, NY)을 이용하여 분석되었다. 우선, 프로그램의 실시 전과 후의 사전. 사후 검사를 통해 유아들의 심미적 언어표현과 한자인식의 평균값과 표준편차를 알아보았다. 다음, 프로그램의 처치 효 과를 알아보기 위해, 사전검사를 공변량으로 하여 집단 별로 사후검사 결과에 유의한 차이가 있는지에 대해 공변량분석 (ANCOVA)을 실시하였다.

이 프로그램의 내용, 교수방법 및 시행효과에 대해 전반적 으로 평가를 위해 유아 6 명과 4 명의 교사를 대상으로 포커스 그룹 면담(FGI)을 실시하였다. 프로그램에 대한 유아들의 전 반적 반응을 알아보기 위해 포커스 그룹 면담 내용을 유아 흥 미성과 프로그램의 난이도로 범주화하여 반구조화 질문으로 구성하였고, 프로그램에 대한 교사들의 인식을 알아보기 위 한 내용으로 교수내용, 교수방법, 현장 적용성 및 프로그램 효 과의 범주로 반구조화 질문을 구성하여 도입질문, 전개질문, 마무리 질문의 순으로 진행하였다. 다음, 면담의 전반 과정을 녹음하고 전사하여 자료를 구성하였으며, 유아교육 전공 연구 생 2 명과 연구자가 함께 분석을 통해 결과를 도출하였다. 또한 프로그램 전반 과정 중에 나타난 유아의 심미적 언어표현 및 한자인식에서 나타난 변화를 질적으로 살펴보았다.

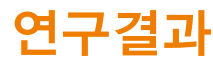

\section{고전시가를 활용한 언어교육 프로그램과 유 아의 심미적 언어표현}

\section{고전시가를 활용한 언어교육 프로그램이 유아 의 심미적 언어표현에 미치는 효과}

고전시가를 활용한 언어교육 프로그램의 시행 전 실험집단과 통제집단 유아의 심미적 언어표현의 차이를 검증하기 위해 두 집단 간 사전 동질성 검증을 시행하였다. 그 결과는 Table 5 와 같이, 두 집단은 판단하기, 상상하기, 좋아하는 부분 언급하기, 감정표현 및 연상하기에서 모두 차이가 없었다.

고전시가를 활용한 언어교육 프로그램이 유아의 심미적 언 어표현에 미치는 효과를 검증하기 위하여 실험집단과 통제집 단의 심미적 언어표현의 사전점수를 공변량으로 집단 별 사후 검사 점수의 차이를 검증하는 공변량분석을 실시하였다. 두 집단 간 교정된 사후 심미적 언어표현의 통계적 유의성을 검 증한 결과는 Table 5 와 같다. 심미적 언어표현의 두 집단 간 교 정된 사후검사 평균점수의 통계적 유의성을 검증한 결과, 심 미적 언어표현 전체 $(F=35.64, d f=1, p<.001)$ 에서 실험집단 의 교정평균 점수가 통제집단보다 유의하게 높았다. 구체적으 로 살펴보면, 상상하기 $(F=12.68, d f=1, p<.01)$, 좋아하는 부 분 언급하기 $(F=9.11, d f=1, p<.01)$, 감정표현 $(F=6.40, d f=1$, $p<.05)$ 및 연상하기 $(F=9.58, d f=1, p<.01)$ 모두에서 두 집 단 간의 차이가 유의하게 나타났다. 
Table 6

Covariance Analysis of Aesthetic Linguistic Expressions

\begin{tabular}{|c|c|c|c|c|c|}
\hline Division & Sources of Variance & Sum of Square & $d f$ & Mean Square & $F$ \\
\hline \multirow[t]{4}{*}{ Judging } & Covariance & 20.26 & 1 & 20.26 & $71.15^{* * *}$ \\
\hline & Group & .91 & 1 & .91 & 3.21 \\
\hline & Error & 27.05 & 95 & .29 & \\
\hline & Sum & 539.00 & 98 & & \\
\hline \multirow[t]{4}{*}{ Imagining } & Covariance & 2.00 & 1 & 2.00 & $5.08^{*}$ \\
\hline & Group & 5.00 & 1 & 5.00 & $12.68^{* *}$ \\
\hline & Error & 37.47 & 95 & .39 & \\
\hline & Sum & 744.00 & 98 & & \\
\hline \multirow{4}{*}{$\begin{array}{l}\text { Recalling } \\
\text { favorite parts }\end{array}$} & Covariance & 17.09 & 1 & 17.09 & $42.39^{* * *}$ \\
\hline & Group & 3.67 & 1 & 3.67 & $9.11^{* *}$ \\
\hline & Error & 38.30 & 95 & .40 & \\
\hline & Sum & 331.00 & 98 & & \\
\hline \multirow[t]{4}{*}{ Expressing emotions } & Covariance & 3.98 & 1 & 3.98 & $10.11^{* *}$ \\
\hline & Group & 2.52 & 1 & 2.52 & $6.40^{*}$ \\
\hline & Error & 37.37 & 95 & .39 & \\
\hline & Sum & 444.00 & 98 & & \\
\hline \multirow[t]{4}{*}{ Associating } & Covariance & 5.96 & 1 & 5.96 & $12.63^{* *}$ \\
\hline & Group & 4.52 & 1 & 4.52 & $9.58^{* *}$ \\
\hline & Error & 44.86 & 95 & .47 & \\
\hline & Sum & 419.00 & 98 & & \\
\hline \multirow[t]{4}{*}{ Total } & Covariance & 117.27 & 1 & 117.27 & $44.08^{* * *}$ \\
\hline & Group & 94.81 & 1 & 94.81 & $35.64^{* * *}$ \\
\hline & Error & 252.73 & 95 & 2.66 & \\
\hline & Sum & 11259.00 & 98 & & \\
\hline
\end{tabular}

${ }^{*} p<.05 .{ }^{* *} p<.01 .{ }^{* * *} p<.001$.

이 연구에서 개발한 고전시가를 활용한 언어교육 프로그램 은 유아의 심미적 언어표현을 증진시킨다. 구체적으로 이 프 로그램은 유아들이 고전시가의 심상을 통한 상상하기 능력을 높이고, 고전시가의 시적 요소나 내용에 대해 좋아하는 부분 을 언급하는 능력을 높이며, 고전시가와 그림의 이미지를 통해 유아가 느끼는 감정을 표현하는 능력을 증진한다. 마지막으로 유아들은 고전시가의 해당 이미지를 통해 자신의 경험을 연상 하여 반응하는 능력도 높이는 것을 알 수 있다. 한편 판단하기 에서는 실험집단의 교정된 사후점수가 통제집단에 비해 높게 나타났으나 통계적으로 유의한 차이는 없는 것으로 나타났다.

고전시가를 활용한 언어교육 프로그램이 유아 의 심미적 언어표현에 가져온 변화

이 프로그램에서 유아들에게 시와 해당하는 그림을 보여주면
서 유아들과 함께 상상하여 말로 표현하게 하는 놀이를 하였 다. 사전검사에서 유아들은 보통 그림과 시에서 나오는 내용 을 그대로 말하는 경우가 많았다. 예를 들어, 사전검사에서 웬 카이밍(温凯铭, 가명)에게 <연못에서(小池)>를 들려주고 해 당 그림을 보여주고 나서 "(이 아이들)그들은 왜 여기에 있을 까?", "(이 아이들은)그들은 무슨 생각을 하고 있는지 상상해 서 말해볼 수 있니?”라는 질문에 “놀고 있어요”, “잘 모르겠어 요”라고 대답을 하였다. 그러나 사후검사에서 웬카이밍은 나 름대로 상상하여 표현하는 모습을 보였다. 이 유아는 그림을 보면서 “이 아이들은 연못에서 잠자리랑 같이 놀고 있어요. 연 꽃이 뾰족하게 돋으니 잠자리들이 연꽃위에 날아 앉아 꽃이 피기를 기다리고 있어요.”라고 그림속의 인물과 경물에 대해 나름대로 상상하여 표현하는 모습을 보였다.

또 다른 예시로, 사전검사에서 유아들에게 고전시가 <시골 생활(村居)>을 들려주고 그림을 보여주었을 때 유아들은 “그 
Table 7

Wen Kaiming's Pre-Post Answers on the Classical Poem "Pond"

\begin{tabular}{|c|c|c|}
\hline Question & Pre-test & Post-test \\
\hline $\begin{array}{l}\text { Why are they here? } \\
\text { (他们为什么会在这里呢?) }\end{array}$ & $\begin{array}{l}\text { “They are playing.” } \\
\text { (他们在玩。) }\end{array}$ & $\begin{array}{l}\text { “They're playing with the dragonflies..” } \\
\text { (他们在跟蜻蜓一起玩呢。) }\end{array}$ \\
\hline $\begin{array}{l}\text { Can you imagine what they're thinking? } \\
\text { (你能想象一下它们在想什么呢? ) }\end{array}$ & $\begin{array}{l}\text { “I'm not sure." } \\
\text { (不知道。) }\end{array}$ & $\begin{array}{l}\text { “These children are playing with dragonflies in the pond. The lotus } \\
\text { flowers are pointed and the dragonflies are flying over the lotus and } \\
\text { waiting for it to bloom.” } \\
\text { (他们在跟蜻蜓一起玩, 荷花尖尖地长出来, 蜻蜓飞到它们 } \\
\text { 身上等着它们开花。) }\end{array}$ \\
\hline
\end{tabular}

Table 8

Su Pinru's Pre-Post Answers on the Classical Poem "The Willow"

\begin{tabular}{|c|c|c|}
\hline Question & Pre-test & Post-test \\
\hline $\begin{array}{l}\text { “Why are they here?” } \\
\text { (他们为什么会在那里呢?) }\end{array}$ & $\begin{array}{l}\text { “They're flying kites.” } \\
\text { (好像是在放风筝。) }\end{array}$ & $\begin{array}{l}\text { “Don't you think this tree looks like a girl's braided hair? They fly } \\
\text { kites while watching the beautiful scenery." } \\
\text { (树枝像小女孩的辫子，两个小朋友在美丽的风景下放风 } \\
\text { 筝。) }\end{array}$ \\
\hline
\end{tabular}

"My mom braided my hair in the morning (pointing to her

Can you imagine what they're thinking? (你能想象一下他们在想什么呢?)
“They have a good view." (他们在想为什么风景 这么美。) braided hair). Pretty, isn't it? This tree looks like my braided hair and it is dancing in the wind. They are thinking about why the willow tree dances so beautifully."

(指着自己的辫子)，我妈妈给我扎的辫子，漂亮吗? 这棵树的 树枝像我的辫子, 风吹着树在跳舞,两个小朋友在边欣党风 景边玩想着柳树跳舞跳得真好看。)
는 왜 여기에 있을까?”, “그는 무슨 생각을 하고 있는지 상상해 서 말해볼 수 있니?”라는 물음에 “그들은 연 날리고 있어요", “경치가 좋아서요."라고 대답하였다. 하지만, 이 프로그램 시 행 후, 많은 유아들은 비유를 사용하여 표현을 하는 모습을 보 였다. 쑤피인루(苏品儒, 가명)는 그림 속의 버드나무를 자신의 땋은 머리에 비유하였고 또 나무가 바람에 춤을 추고 있다고 표현하였다. 이는 그가 버들나무의 아름다움을 나름대로 비유 의 수법으로 표현을 할 수 있음을 알 수 있었다.

\section{고전시가를 활용한 언어교육 프로그램과 유 아의 한자인식}

\section{고전시가를 활용한 언어교육 프로그램이 유아 의 한자인식에 미치는 효과}

고전시가를 활용한 언어교육 프로그램의 시행 전 실험집단과 통제집단 유아의 한자인식에 차이가 있는지를 검증하기 위해 두 집단 간 평균점수의 차이를 검증하는 동질성 검사를 실시
하였다. 그 결과는 Table 9와 같이 제시되었고, 두 집단은 한자 찾기, 그림이 나타내는 한자 고르기 및 한자가 나타내는 그림 고르기에서 모두 차이가 없음을 알 수 있다.

이 연구에서 개발한 고전시가를 활용한 프로그램이 유아의 한자인식에 미치는 효과를 검증하기 위하여 실험집단과 통제 집단의 한자인식의 사전점수를 공변량으로 집단별 사후 검사 점수의 차이를 검증하는 공변량분석을 실시하였다. 한자인식 의 두 집단 간 교정된 사후검사 평균점수의 통계적 유의성을 검증한 결과(Table 10$)$, 한자인식 전체 $(F=12.61, d f=1, p<.01)$ 에서 실험집단의 교정평균 점수가 통제집단보다 유의하게 높았다. 구체적으로 살펴보면, 한자변별 $(F=7.05, d f=1, p<$ $.01)$, 그림보고 한자 고르기 $(F=5.62, d f=1, p<.05)$ 에서 두 집 단 간의 차이가 유의하였으며 한자보고 그림 고르기 $(F=2.74$, $d f=1$ )에서는 두 집단 간 차이는 유의하지 않았다. 즉, 이 연구 에서 개발한 고전시가 언어교육 프로그램은 유아의 한자인식 뿐만 아니라 한자 찾기, 그림이 나타내는 한자 고르기에서는 향상시키는 효과가 있었으나 한자가 나타내는 그림 고르기 과 제에서는 효과가 없었다. 이는 한자의 모양과 의미를 연결시 
Table 9

Difference Between Groups in Chinese Character Recognition Before Intervention

\begin{tabular}{|c|c|c|c|c|c|}
\hline Division & Group & $N$ & $M$ & $S D$ & $t$ \\
\hline \multirow{2}{*}{ Finding Chinese characters } & Experimental group & 49 & 6.39 & 2.22 & \multirow{2}{*}{-1.25} \\
\hline & Control group & 49 & 6.92 & 1.97 & \\
\hline \multirow[b]{2}{*}{ Choosing Chinese characters that the picture represents } & Experimental group & 49 & 2.78 & 1.56 & \multirow{2}{*}{.49} \\
\hline & Control group & 49 & 2.63 & 1.33 & \\
\hline \multirow[b]{2}{*}{ Picking a picture represented by Chinese characters } & Experimental group & 49 & 1.63 & 1.42 & \multirow{2}{*}{-.49} \\
\hline & Control group & 49 & 1.78 & 1.45 & \\
\hline \multirow{2}{*}{ Total } & Experimental group & 49 & 10.80 & 4.31 & \multirow{2}{*}{-.65} \\
\hline & Control group & 49 & 11.33 & 3.76 & \\
\hline
\end{tabular}

Table 10

Covariance Analysis of Chinese Character Recognition

\begin{tabular}{|c|c|c|c|c|c|}
\hline Division & Sources of Variance & Sum of Square & $d f$ & Mean Square & $F$ \\
\hline \multirow[t]{3}{*}{ Finding Chinese characters } & Covariance & 249.58 & 1 & 249.58 & $280.30^{* * *}$ \\
\hline & Group & 6.28 & 1 & 6.28 & $7.05^{* *}$ \\
\hline & Sum & 6151.00 & 98 & & \\
\hline \multirow{2}{*}{$\begin{array}{l}\text { Choosing Chinese characters that the } \\
\text { picture represents }\end{array}$} & Covariance & 95.60 & 1 & 95.60 & $143.49^{* * *}$ \\
\hline & Sum & 1276.00 & 98 & & \\
\hline \multirow{3}{*}{$\begin{array}{l}\text { Picking a picture represented by Chinese } \\
\text { characters }\end{array}$} & Covariance & 111.56 & 1 & 111.56 & $170.85^{* * *}$ \\
\hline & Group & 1.79 & 1 & 1.79 & 2.74 \\
\hline & Error & 62.03 & 95 & .65 & \\
\hline \multirow{2}{*}{ Total } & Error & 257.22 & 95 & 2.71 & \\
\hline & Sum & 19205.00 & 98 & & \\
\hline
\end{tabular}

${ }^{*} p<.05 .{ }^{* *} p<.01 .{ }^{* * *} p<.001$.

키는 한자 교육 프로그램이 유아의 한자인식에 유의한 효과를 미친다는 선행연구와 일치하는 결과이다(Li \& Liu, 2007).

\section{고전시가를 활용한 언어교육 프로그램의 참여 한 유아의 한자인식의 변화}

고전시가를 활용한 언어교육 프로그램 중 매 수의 시에서 시 내 용의 실마리를 엮을 수 있는 상형자를 뽑아 유아들과 함께 글 자의 유래, 모양 및 의미를 탐색하는 활동을 하였다. 이 프로그 램 전반 과정에서 연구자는 유아들의 시 중에 나타난 상형자에
대한 반응을 통해 그들의 한자인식의 변화를 관찰하고자 하였 다. 쏘우뮈천(省默晨, 가명)은 2차시의 <거위(鹅)> 중 '水(물)'에 대한 교사의 “이 글자가 무슨 모양으로 생겼나요?”라는 질문에 아무런 반응을 하지 않았다. 교사는 유아들에게 물이 흐르는 그림을 보여주고 유아들과 함께 그림과 한자의 비슷한 곳에 대 해 이야기를 나누었다. 14 차시 <봄날 밤 단비(春夜喜雨)> 중 “雨 (비)'에 대한 교사의 “이 글자가 무슨 모양으로 생겼나요?”라는 질문에 쏘우뭐천은 “(글자)안에 빗방울이 있어요.”라고 말하였 다. 즉, ‘雨(비)’를 해당 시의 이미지와 연결한 것이다.

또한 이 프로그램이 유아의 한자인식에 미치는 효과를 알아 
Table 11

Xiao Mochen's Change of Chinese Character Recognition

\begin{tabular}{lll}
\hline \multicolumn{1}{c}{ Question } & \multicolumn{1}{c}{ 2nd Class } & \multicolumn{1}{c}{ 11th Class } \\
\hline “What shape does this letter look like?” & (She shakes her head at the teacher.) & “Teacher, I think there are some raindrops inside.” \\
这个字像什么呢? & (看着研究者摇头。) & (老师, 我觉得这个字里面有雨滴。) \\
\hline
\end{tabular}

Table 12

Changes in the Name in Wang Hongli's Paintings

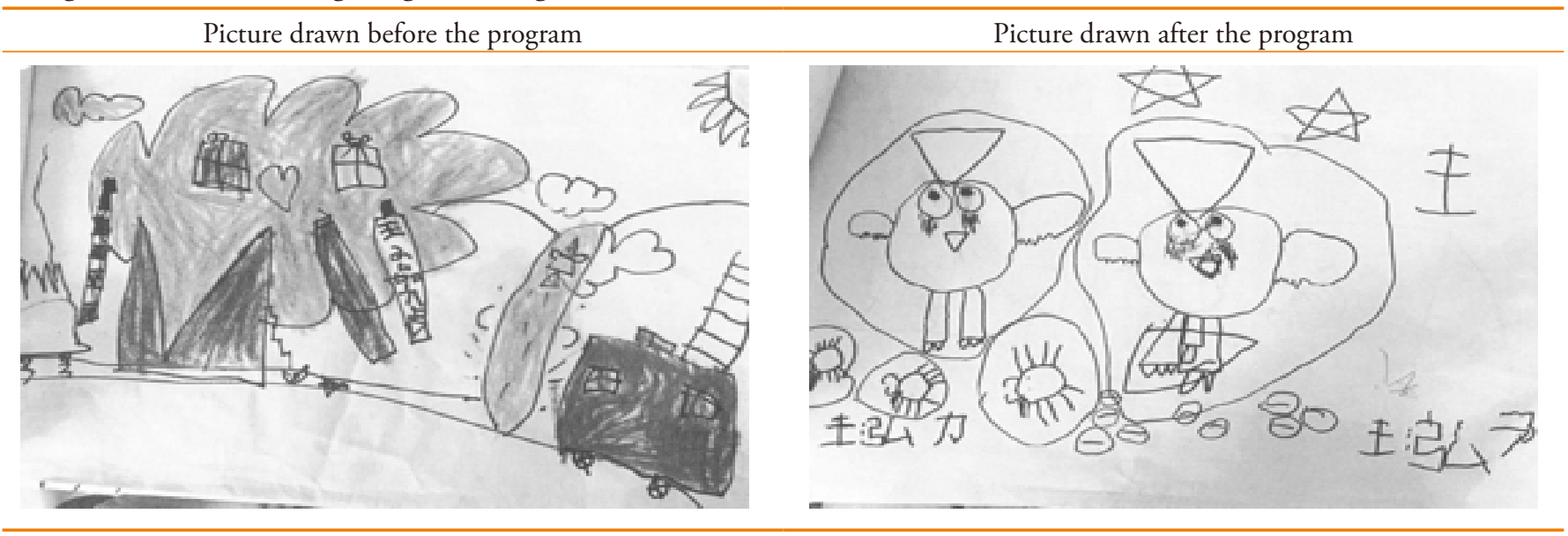

보기 위해 유아의 사전.사후 그림에 나타난 이름 쓰기 변화에 대 해 알아보았다. 왕훙리(王泓力, 가명)의 프로그램 시행 전과 후 의 이름쓰기 변화는 단독 상형문자 “王”을 제외한 나머지 글자 에서 한자의 특성이 보다 뚜렷이 나타나는 것을 알 수 있었다. 프로그램 시행 전에 이 유아가 그린 그림에 나타난 이름을 살 펴보면, 간단한 선, 삼각형, 네모 등 단순하고 창안적인 글자 (invented characters) 쓰기 형태가 나타나 있는 것을 볼 수 있다. 반면, 프로그램 시행 후에 그린 그림에서 나타난 이름을 살펴보 면, 한자의 형태가 비교적 뚜렷하고 보다 발전된 모습을 보인다.

\section{고전시가를 활용한 언어교육 프로그램을 평 가하기 위한 포커스 그룹 면담 결과}

이 연구는 고전시가를 활용한 언어교육 프로그램을 개발 및 시행한 후에 12 명의 유아와 4 명의 교사를 대상으로 포커스 그 룹 면담을 실시하여 프로그램의 전반적 내용 및 효과에 대해 전반적으로 평가하였다. 다음, 포커스 그룹 면담 과정 전체를 녹음한 후 전사하여 분석하였다.

포커스 그룹 면담을 통해, 이 프로그램은 유아의 흥미를 충 분히 유발하였음을 알 수 있었다. 유아 흥미성은 당시 읆기 프 로그램을 수행하는 과정에 유아들이 흥미를 느꼈는가의 의미 를 나타낸다. 유아교육 프로그램에서 유아의 발달 특성에 맞
고 그들의 흥미를 충분히 끌어낼 수 있어야만 유아의 몰입을 통한 놀이와 학습이 이루어질 수 있다. 유아들은 고전시가를 활용한 이 프로그램을 수업을 넘어서 '고전시가 놀이'로 즐겼 음을 알 수 있었다. 그 중 <낚싯대 드리운 아이(小儿垂钓)>를 다시 읅어주고 이미지를 보여주었을 때 유아들은 수업시간에 했던 '낚시하는 아이' 극 놀이를 떠올리면서 놀이에 대한 즐거 웠던 기억을 다시 말하는 모습을 보였다.

연구자: 선생님이랑 같이 수업을 할 때 무엇이 제일 재미있었 니? 루쥐인이(卢俊奕, 가명): <낚싯대 드리운 아이(小儿垂钓)> 를 배울 때 낚시하는 극 놀이가 너무 재밌었어요. 또 해보고 싶 어요. 떵졔이잉(邓洁莹, 가명): 선생님, 저도 고전시가 놀이를 또 해보고 싶어요.
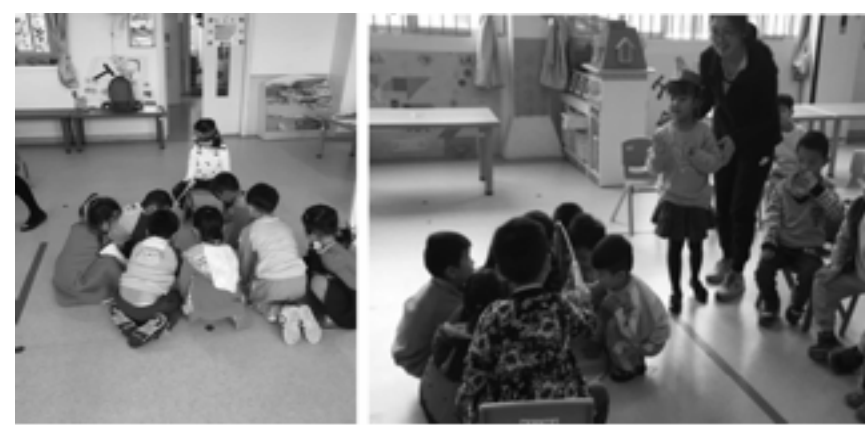

Figure 2. A "Fishing Child" Play 
연구자: 고전시가 수업에서 무엇을 했던지 또 기억나는 것이 있니? 왕후웅리(王红丽, 가명): 선생님이 나무가 그려진 그림 에 잎을 붙이는 게임을 했어요.

연구자: 응, 맞아. 우리 <버들 (咏柳)>이라는 시를 공부했 을 때 함께 버드나무 잎 붙여서 예쁜 그림을 만들었었지. 천린이(陈林毅, 가명): 나뭇잎이 가늘었어요. 눈썹 같았어요. 눈썹나무를 만들었어요.류하우쥔(刘浩俊, 가명): 눈썹나무? (웃음)

교사 포커스 그룹 면담에서도 교사들은 당시 읆기 프로그 램의 유아 흥미성에 대해 언급하였다.

프로그램에서 제일 인상 깊었던 것이 <낚싯대 드리운 아 이(小儿垂钓)> 수업을 할때, 선생님이 준비한 낚시놀이 교 구를 아이들이 너무 좋아했던 것 같아요. 한 아이가 낚시 하는 역을, 또 다른 아이가 길을 묻는 사람 역을 맡고 나 머지 8 명 아이들이 물고기 역을 맡아 극 놀이를 하던 장 면이 아직도 생생해요. 모든 아이들이 다 참여할 수 있 도록 극 놀이를 두세 번 했던 것이 너무 좋았어요. 애들 이 너무 재미있어 했고 쉽게 시의 내용을 이해했지요. (B조, 리샤오화(李晓华, 가명) 교사)

또한, 포커스 그룹 면담을 통해 고전시가를 활용한 언어교 육 프로그램은 유아의 발달 특성에 적합함을 알 수 있었다. 유 아 발달 적합성에 대한 평가 내용은 아래의 사례에서 볼 수 있 듯이, 교육목표의 측면에서, 교사들은 유아들에게 당시를 암 기할 것을 요구한 것이 아니라 유아들의 흥미를 유발할 수 있 는 교수법으로 프로그램을 시행하여 놀이 위주의 유아 발달 특성에 적합하다고 말하였다. 또한 프로그램 당시 선정 시 수 요 조사 면담에 참석했던 것을 떠올리면서 당시 내용이 대체 로 유아의 발달에 적합하다고 말했다. 마지막으로 궈후이민 (郭慧敏, 가명) 교사는 매 회기 프로그램 시간 측면으로부터 유아의 발달 적합성에 대해 말하였다.

이 프로그램에서 선생님은 유아들에게 고전시의 의미를 일방 적으로 유아들에게 전달하거나 암기할 것을 요구하지 않은 반 면, 아들이 좋아하는 극 놀이, 미술놀이, 게임 등으로 표현하기 등 형식을 적극 활용하여 4세 유아의 발달 특성에 맞는 심미적 교수 방법으로 수업을 진행하셔서 좋았던 것 같아요. 전반적으 로 4세 유아들의 발달에 적합한 프로그램이었다고 생각해요. (A조, 양슈리(杨秀丽, 가명) 교사)
포커스 그룹 면담을 통해 고전시가를 활용한 언어교육 프 로그램이 유아교육 현장에 적합함을 알 수 있었다. 면담을 통 해 교사들은 교육 현장에서 유아들에게 한자 인식을 증진시키 는 교수법에 대해 나름대로 고민하고 있음을 알 수 있었다. 또 한 이 연구에서 사용한 상형자를 활용한 한자 탐색 활동은 유 아들의 흥미를 끌어낼 수 있고 현장 활용에도 용의하다고 말 하였다. 그들은 교사들은 이러한 교수법을 유치원 교육 현장 의 언어활동에서 적극 활용하려고 시도하는 모습도 보였다.

프로그램에서 좋았던 것 중의 하나가, 선생님이 고전시를 가르 칠 때 먼저 그림을 보여주면서 애들한테 관찰하게 하고 나름대 로 상상을 하게 하였잖아요. 이는 아이들의 이해능력과 상상력 향상에 아주 좋은 것 같아요. 저희가 선생님의 이런 방식을 따 라 해도 되죠? 요즘 저희가 애들한테 동화책 읽어줄 때도 이런 방식으로 하고 있어요.(B조, 주친리(朱秦丽, 가명) 교사)

이상의 면담 분석을 통해 당시 읆기 프로그램은 4 세 유아의 흥미성을 충분히 끌어낼 수 있었고, 유아의 발달 특성에 적합 할 뿐 만 아니라 현장 적용에도 용이함을 알 수 있었다. 이러한 결과는 당시 을기 프로그램을 경험한 유아들의 심미적 언어표 현 및 한자인식에 향상이 나타난 배경을 설명해준다. 즉 양적 연구를 통해 처치 여부에 따른 효과를 검증하였고, 질적 연구 의 접근을 통해 프로그램에 참여한 유아들에게 어떠한 변화가 나타났는지를 확인할 수 있었다.

\section{논의 및 결론}

이 연구는 만 4세 중국인 유아의 심미적 언어표현과 한자인식 을 향상시킬 수 있는 고전시가를 활용한 언어교육 프로그램 을 개발하고 이 프로그램이 유아의 심미적 언어표현과 한자인 식을 향상시켰는지 통계적으로 검증하고, 프로그램 시행 전반 과정에서 유아의 심미적 언어표현과 한자인식에 나타난 변화 를 질적으로 살펴보았다. 연구의 결과에 대해 논의하며 결론 을 내리면 다음과 같다.

첫째, 고전시가를 활용한 언어교육 프로그램은 4세 중국 유 아의 심미적 언어표현에 효과가 있다. 고전시가를 활용한 언 어교육 프로그램은 유아의 심미적 언어표현 중 상상하기, 좋 아하는 부분 언급하기, 감정표현 및 연상하기에 긍정적 영향 을 미친다. 고전시가를 활용한 언어교육 프로그램에서는 고 전시가의 이미지가 강한 특성을 활용하여 시를 읆고 이미지를 
포착하여 심미적인 언어로 표현을 하고 신체 동작과 그림 표 현과 같은 예술 활동을 통해 유아들의 심미적 언어표현이 증 진된다. 이는 유아들에게 은유와 상상을 자극하는 언어를 사 용하고 그들의 흥미를 자아내어 몰입할 수 있는 심미적 매체 를 제공하며, 나아가 유아의 심미적 생각과 느낌을 다양한 예 술 활동과 언어로 표현하게 하는 유아 당시 교수법에 새로운 시사점을 제공한다. 그러나 시가의 내용이나 시적인 요소에 대해 판단하게 하는 과제는 유아들의 논리적 사고를 바탕으로 하기 때문에 4세 유아에게 다소 어려움이 있다.

4 세 유아들은 언어를 습득하는 과정에 즐거운 말놀이를 통 해 언어를 탐색하고 언어에 대한 감각을 키워나간다(S. J. Kim, 2012). 또한 심상과 이미지에 대한 강한 포착력을 가지고 있어 마음속에 아름다운 세계를 상상하는 지향성을 가지고 있으며, 새로운 언어적·심미적 자극을 자신의 경험과 연결시켜 인지능 력을 끓임없이 높여나간다. 이는 유아교육 현장에서 시 문학 지도를 할 때 심미적인 접근으로 유아의 심미적 언어표현을 증진시키는 데 시사점을 줄 수 있다.

둘째, 고전시가를 활용한 언어교육 프로그램은 4 세 중국 유 아의 한자인식에 효과가 있다. 이 프로그램에서 유아들과 함 께 갑골문자의 유래를 탐색하고, 사물의 모양으로부터 상형문 자의 모양을 예측하며 반대로 상형문자로부터 사물의 모양을 알아보는 훈련을 통해 유아의 전반적 한자인식을 증가하는 효 과를 가져왔다. 구체적으로 고전시가를 활용한 언어교육 프 로그램은 한자인식의 하위영역인 한자 찾기, 그림이 나타내 는 한자 고르기에서는 긍정적 효과가 있으나, 한자가 나타내 는 그림 고르기 과제에서는 효과가 유의하지 않았다. 이는 상 형문자를 활용한 한자 교수활동이 유아가 한자를 인식하는 데 효과적이라고 보고한 연구(Loh et al., 2013)와 맥을 같이한다. 또한 4세 유아들은 그림에 맞는 한자를 고르는 과제를 한자에 맞는 그림을 고르는 과제보다 더 수월히 수행한다. 이는 4세 유아들의 구체적인 그림으로부터 추상적인 한자를 끌어내는 사고방식을 보여준다. 프로그램에서는 매 시에서 제일 간단하 고 사물의 모양을 제일 잘 드러내는 상형문자를 선정하여 프 로그램 구성에 포함시켰다. 이는 중국 유아들에 대한 한자 습 득 연구(Yu, 2006)에서 제기한 유아 한자 교육은 실제 의미의 맥락 속에서 이루어진다는 점을 기반으로 한 것이다. 이 연구 는 한자의 형.의(形.意)의 특성을 고려해 보았을 때, 4 세 중국 유아는 유치원에서 공식적인 문해학습이 이루어지기 전에 발 달적으로 한자 읽기와 쓰기가 이루어지지 않으나 발현적 문해 습득 과정에 적절한 문해적 노출에 의해 한자의 모양과 의미 에 대한 인식을 가지고 있음을 입증하였다. 또한 이 연구에서
는 4세 유아의 발달수준을 고려하여 유아들이 쉽게 접할 수 있 는 명사 상형문자를 사용하였음에도 불구하고 유아들은 그림 을 보고 대응되는 한자를 찾아내는 과제에서 한자를 보고 대 응되는 그림을 찾는 과제에서 더 높은 수준을 나타냈다. 이는 상형문자의 형성원리와 같은 패턴을 나타내고, 유아들은 문자 보다 그림을 더 쉽게 받아들인다는 것을 알 수 있다. 또한 유아 들이 한자를 접할 때 하나의 그림으로 받아들인다는 연구결과 를 지지한다(Lin, Sun, \& Zhang, 2016). 우선, 한자의 형.의(形. 意)의 특성으로부터 보았을 때, 4 세 중국 유아는 발달적으로 한자에 대한 인식이 점차 이루어지는 시기이다. 그러나 유아 손의 소 근육 발달이 아직 제대로 이루어지지 않음을 감안할 때, 4 세 유아들은 불규칙한 선으로 쓰는 단계를 거쳐 천천히 안정된 형태의 한자 쓰기 과정으로 변화한다. 이는 유아들의 한자 쓰기 중간 단계를 인정하고 그 과정을 통해 유아들이 한 자를 인지하여 향후 공식적 한자 학습을 우한 기초를 다질 수 있음을 시사한다. 또한 한자 쓰기는 4세 유아들에게 있어서 어 려운 과제임으로 장기적인 문해적 노출과 자극이 필요하고 손 의 소 근육 발달이 더 잘 이루어져야 가능해진다는 것을 알 수 있다.

셋째, 고전시가를 활용한 유아 언어교육 활동 중에 교사가 단순히 고전시가의 의미를 유아들에게 전달하거나 외우게 하 는 것은 유아의 발달특성에 어긋날 뿐 만 아니라 유아들로 하 여금 고전시가와 같은 문학작품을 거부하게 되는 원인이 될 수 있다. 따라서 유아의 실생활과 관련된 유의미한 상황에서 구체적이고 체계적인 고전시가 활동을 실시하여 유아들이 자 연스럽게 심미적인 언어로 자신의 느낌과 감정을 표현할 수 있으며 한자에 대해서도 관심을 가지게 할 수 있을 것이다. 또 한 유아기 문학 활동에서 흔히 쓰이는 심미적 교수법을 활용 하여 고전시가를 미술, 음악 및 게임 등 다양한 형식과 결합하 여 교수 방안을 모색하고 그 효과를 다각적으로 검증해볼 필 요가 있음을 시사한다.

이 연구는 학문적 측면, 방법론적 측면 및 실천적 측면에서 연구의 의의를 찾을 수 있다. 우선 학문적 측면으로부터 보았 을 때, 이 연구는 중국의 전통시가를 활용하여 4 세 유아를 대 상으로 한 언어교육 프로그램을 구성 및 시행하여 유아의 심 미적 언어표현 및 한자인식에 미치는 효과를 검증하고자 하였 다. 이는 영어권 나라에서 마더구스와 같은 전통시가를 유아 언어교육과 접목시킨 연구가 활발히 이루어진 반면 아시아권 나라에서는 전통시가를 활용한 연구가 그리 많지 않은 현황에 비추어 중화권 유아를 대상으로 전통시가가 유아의 심미성 발 달과 한자인식에 미치는 효과를 검증함으로써 다양한 문화 집 
단 유아의 언어표현력 및 문자인식의 발달에 대한 이해를 넓 혔다는 데 그 시사점을 둘 수 있다. 또한 이 프로그램에서는 심 미적인 교수법을 사용하여 유아들에게 쉽게, 재밌게 다가갈 수 있었다는 데서도 그 시사점을 찾아볼 수 있다. 이는 한국을 포함한 아시아 나라들에서 전통시가를 활용하여 언어교육을 시행하는데도 시사점을 줄 수 있다. 다음 방법론적 측면으로 부터 보았을 때, 이 연구는 집단 간 비교를 통해 프로그램의 효 과를 검증하는 양적 연구방법과 관찰, 포커스 그룹 면담 등을 통한 질적 연구방법을 동시에 적용하는 병행연구 방법을 사용 하였다. 특히, 유아교육 현장에서의 교사와 프로그램에 참여 한 유아들의 실제 목소리를 담아냈다는 데 의미가 있다. 또한, 이 프로그램이 매주 4 번씩 16 회의 짧은 기간 동안 실시된 것 은 프로그램의 효과를 제외한 다른 요인이 영향을 줄 수 있는 가능성을 배제하기 위한 것임으로 최대한 프로그램의 순수한 효과를 검증하였다는 데서 방법론적 의의를 찾아볼 수 있다. 마지막으로 실천적 측면에서 이 프로그램은 유아교육 현장에 서의 언어교육 활동에 대해 시사점을 주었다는 데서 그 의의 를 가진다.

프로그램의 이러한 교육적 가치에도 불구하고 이 연구는 연구대상 연령이 만 4세 유아에게만 국한된 점, 프로그램이 유 아의 심미적 언어표현과 한자인식에 가져오는 효과가 어떠한 기제를 통해 일어나는지에 대해 엄격히 통제하지 못한 점 등 의 제한점을 지닌다. 따라서 다양한 연령의 유아 또는 한국 유 아 등 문화적으로 더 넓은 집단에 대한 비교 연구를 실시할 수 있을 것이다. 또한 고전시가를 이용한 언어 교육 프로그램이 유아의 언어.문해 발달에 미치는 효과를 더욱 과학적으로 검 증하기 위해 신경과학적 접근을 시도할 수 있을 것으로 본다.

\section{Notes}

This article was presented as a poster at the 2018 Annual Spring Conference of the Korean Association of Child Studies.

\section{Conflict of Interest}

No potential conflict of interest relevant to this article was reported.

\section{References}

\section{In English}

Brooks, P. J. \& Kempe, V. (2012). Language development. Chichester, UK: BPS Blackwell.

Ellis, N. C., \& Beaton, A. (1993). Psycholinguistic determinants of foreign language vocabulary learning. Language Learning, 43(4), 559-617. doi:10.1111/j.1467-1770.1993.tb00627.x

Erika, H. (2001). Language development (2nd ed.). Belmont, CA: Wadsworth.

Everson, M. E. (2011). Best practices in teaching logographic and non-roman writing systems to L2 learners. Annual Review of Applied Linguistics, 31, 249-274. doi:10.1017/ S0267190511000171

Grafinger, D. J. (1988). Basics of instructional systems development [INFO-LINE Issue 8803]. Alexandria, VA: American Society for Training and Development.

Hay, I., Elias, G., Fielding-Barnsley, R., Homel, R., \& Freiberg K. (2007). Language delays, reading delays, and learning difficulties: Interactive elements requiring multidimensional programming. Journal of Learning Disabilities, 40(5), 400409. doi:10.1177/00222194070400050301

Li, H., Shu, H., McBride-Chang, C., Liu, H., \& Peng, H. (2012). Chinese children's character recognition: Visuoorthographic, phonological processing and morphological skills. Journal of Research in Reading, 35(3), 287-307. doi:10.1111/j.1467-9817.2010.01460.x

Lin, D., Sun, H., \& Zhang, X. (2016). Bidirectional relationship between visual spatial skill and Chinese character reading in Chinese kindergartners: A cross-lagged analysis. Contemporary Educational Psychology, 46, 94-100. doi:10.1016/j.cedpsych.2016.04.008

Lo-Philip, S. W. (2014). Chinese L2 literacy practices: material and sociocultural considerations. Language and Education, 28(3), 237-250. doi:10.1080/09500782.2013.819010

Many, J. E., \& Wiseman, D. L. (1992). Analyzing versus experiencing: The effects of teaching approaches on student's response. In J. Many \& C. Cox (eds). Reader stance and literary understanding: Exploring the theories, research, and practice. Norwood, NJ: Ablex.

Opitz, B., Schneiders, J., Krick, C., \& Mecklinger, A. (2014). Selective transfer of visual working memory training on Chinese character learning. Neuropsychologia, 53, 1-11. doi:10.1016/j.neuropsychologia.2013.10.017

Ruan, Y., Georgiou, G., Song, S., Li, Y., \& Shu, H. (2018). Does writing system influence the associations between phonological awareness, morphological awareness, and reading? A meta-analysis. Journal of Educational 
Psychology, 110(2), 180-202. doi:10.1037/edu0000216

Schirrmacher, R. (2005). Art and creative development for young children. Albany, NY: Delmar Publishers.

Terrett, G., White, R., \& Spreckley, M. (2013). A preliminary evaluation of the parent-child Mother Goose Program in relation to children's language and parenting stress. Journal of Early Childhood Research, 11(1), 16-26. doi:10.1177/1476718X12456000

Yopp, R. H., \& Yopp, H. K. (2000). Sharing informational text with young children. The Reading Teacher, 53(5), 410-423.

\section{In Korean}

Choi, N. (2007). The effects of Korean alphabet knowledge, phonological awareness, phonological processing on kindergarteners Hangul words reading (Doctoral dissertation). Retrieved from http:// www.riss.kr/link?id=T10867266

Eom, E. N., Kang, J. W., \& Bark, S. (2007). The effects language game through traditional children's songs on enhancement of children's a language expression and peer relationships. Journal of Korean Council for Children's Rights, 11(2), 265290.

Han, C. H., Choi, N., \& Yi, S. -H. (2018). The effects of language teaching programs through Tang poems on phonological awareness of Chinese 4-year-old children. Journal of LearnerCentered Curriculum and Instruction, 18(8), 415-442.

Jung, Y. Y., \& Hwang, H. (2013). The effects of young children's verbal expression ability on their prosocial behaviors. Journal of Korean Child Care and Education, 9(6). 5-23.

Kim, J. (2016). Action research on aesthetic approach to poetic activities for young children (Master's thesis). Retrieved from http://www.riss.kr/link?id=T14019576

Kim, J.-S. (2002). Effects of poetry instruction based on readerresponse theory (Doctoral dissertation). Retrieved from http://www.riss.kr/link?id=T8140580

Kim, S. J. (2012). Effects of speaking activity through traditional children's songs on young children's linguistic expressions and word recognition ability (Master's thesis). Retrieved from http://www.riss.kr/link?id=T12955272

Yoon, H.-K. (2001). The characteristics of decoding process in Korean Scripts, Hangul. The Korean Journal of Human Development, 8(1), 27-43.

\section{In Others}

Dong, Q., Li, H., Wu, X. C., Rao, X. W., \& Zhu, J. (2014). The roles of Morphological awareness, phonological awareness and rapid naming in linguistic skills development of Chinese kindergartener: evidence from a longitudinal study. Studies of Psychology and Behavior, 12(2), 207-211.

Li, H., \& Liu, L. W. (2007). Curricular and instructional influences on early literacy attainment: Evidence from Beijing, Hong Kong and Singapore. Early Childhood Education, 358(2), 20-26. doi:10.3969/j.issn.1004-4604-B.2007.02.006

Liu, F., \& Teng, S. (2013). On the children Tang poetry education. Studies in Early Childhood education, 1, 44-48.

Loh, K. Y., Tse, S. K., \& Tsui, S. K. (2013). A study of the effectiveness of a school-based Chinese characters curriculum for non-Chinese speaking kindergarteners: HongKong experience. Hanja hanmun gyoyuk[한자한문교육], 30, 277 323. http://www.riss.kr/link?id=A99721197

Lu, Y. (2015). The application of ink form in the teaching of kindergarten ancient poems. Good Parents, 2, 59-61.

$\mathrm{Xu}, \mathrm{L}$. L. (2015). A probe into the teaching of young children's ancient poems. Elementary School Science, 1, 153-153.

Yang, J. Z., \& Liu, Y. (2003). A aesthetic study of classical poetry. J ournal of Liaoning normal U niversity, $26(2), 73-75$.

Yu, Z. Y (2006). On the acquisition of early reading and writing. Early Childhood Education, 322(2), 19-23.

Zhang, Y., \& Yang, W. X (2013). Lack of literature on the children's poetry and solutions. Journal of Social Science of Harbin Normal University, 3(16), 111-113.

\section{ORCID}

Han Chunhua

Naya Choi

Yi Soon-Hyung https://orcid.org/0000-0002-8515-0141 http://orcid.org/0000-0001-9189-9370 http://orcid.org/0000-0002-3381-1788
Received September 7, 2018 Revision received October 17, 2018

Accepted October 18, 2018 